\title{
SZOCIÁLIS REPREZENTÁCIÓ, AHOGY A KÖZÖSSÉG MEGSZELÍDÍTI AZ ISMERETLENT
}

\author{
KISS PASZKÁL \\ az Eötvös Loránd Tudományegyetem Pedagógiai és Pszichológiai Kar \\ Társadalom- és Neveléspszichológiai Tanszékének \\ tanszékvezetö egyetemi docense \\ kiss.paszkal@ppk.elte.hu
}

\begin{abstract}
A szociális reprezentáció elmélete sajátos tanulási folyamatot ragad meg, melynek során a közösség komplex összefüggéseket saját nyelvére fordit. Ez a tanulás több szempontból is kivételes. Egyszerre szolgálja a közösségi kapcsolat fenntartását és az új jelenségnek a mindennapokban is érthetö reprezentációját. Legalább annyira célja a bizonytalannal való megküzdés, az ismeretlen megszeliditése, mint maguknak az ismereteknek a gyarapitása. A megismerés alanya nem az egyén, hanem a közösség, ezért az egyéni megismerési folyamatok helyett a kommunikáció (tömegkommunikáció) szerepe kerül elötérbe. A megismerés kognitív folyamatait nem önmagukban, hanem a társas-társadalmi metafolyamatok hátterén vizsgálja. A szociális reprezentáció szakirodalma számos területen igyekszik követni az új jelenségekkel való megküzdést, legyenek azok új tudományos elméletek (pl. pszichoanalízis), normatív társas-társadalmi reprezentációk (pl. emberi jogok) vagy új technológiai újitások (pl. genetikailag módositott élölények).
\end{abstract}

\section{Bevezetés}

Nem kizárólag tanteremben vagy általában formális tanulási helyzetekben tanulunk. A tanulás során releváns társas (társadalmi) ${ }^{1}$ interakciót sem lehet ezért a tantermi helyzetekre, akár a tanár-diák, akár a diák-diák kölcsönhatásra szükíteni. Egyszerü tehát a kiindulópontunk: az ismeretlen jelenségek megismerésének, a róluk alkotott reprezentáció kialakításának hétköznapi, ám tanulási folyamatként kevésbé vizsgált, kevésbé explicit mechanizmusait javaslom egy kicsit közelebbröl vizsgálni.

A mentális müveleteket különösen érdekes oldalukról, a gyermeki fejlődés felől mutatta be a világ megismerésének szabályszerüségei iránt szenvedélyesen érdeklődő Jean Piaget. Sajnálatos, de nem a pszichológiai szakterületeken átívelő üzenetét minősítő körülmény, hogy a sémák fogalmát és a számítógép-analógiától

\footnotetext{
${ }^{1}$ A jellemzően angolszász szakirodalomban a „szociális”-t inkább interperszonálisnak (társas) érthetjük, a szociális reprezentáció elméleti körében azonban érdemes élni a magyar nyelvi gazdagsággal, és utalni arra, hogy a társas szintet meghaladó társadalmi szinten is zajlik interakció (itt pl. tömegkommunikáció, közgondolkodás folyamatai).
} 
elszakadó megismerési modelleket és elveket is újra fel kellett fedezni egy későbbi generációnak, fokozatosan, a fejlődéselméleti hasznosításnál szélesebb körben is rehabilitálva gondolatait.

A gondolkodás társas összefüggéseivel kapcsolatban ma is úgy él Piaget a szakmai emlékezetben, mint Vigotszkij társas-társadalmi hangsúlyaival szemben az individuális megismerési folyamatok elsőségét hirdető vitapartner. Ezért volt izgalmas sok év után magyarul olvasni a „szociológus” Piaget-t (Piaget, 1965/2005), aki a formális mentális müveletekre alkalmas, a közvetlen érzékleti tapasztalatról leváló megismerés kialakulásának társadalmi feltételeivel kapcsolatosan fogalmazott meg a korabeli francia társadalomtudományi (Durkheim, Lévy-Bruhl) eredmények által is megalapozott sejtéseket (a szónak, matematikában is használatos, erős értelmében). Messzire vezetne például az a kérdés, hogy a gyermek korai egocentrikus gondolkodása és a totális társadalmi rendszerek paternalizmusa között kereshetünk-e közvetlen kapcsolatot. A társadalmi rendszerek, kultúrák történeti változása és az ontogenetikus fejlődés közötti párhuzam mérlegelése is hosszabb, elemző kifejtést kívánna. Most csak arra hívnám fel a figyelmet, hogy a fent említett levezetésben a Piaget elmélete szerint új minőséget (lásd logikai érzék) jelentő absztrakt fogalmi gondolkodásnak legalábbis a mozgatórugóit a társadalmi feltételek adják.

Ugyanazok a francia társadalomtudósok, akik Piaget-re is hatottak, vele együtt nagy hatást gyakoroltak egy fiatal társadalomlélektani gondolkodóra, Serge Moscovicire is. Ezt a hatást egy, nem is olyan régen magyarul megjelent gyüjteményes kötet (Moscovici, 2002) több tanulmánya hủen dokumentálja. Nem kisebb célt tüzött Moscovici maga elé, mint hogy a tudományossá váló szociálpszichológa karakterét adó és egyik legfontosabb exportcikkévé váló attitüdkutatás amerikai individualista hagyományának alternatíváját nyújtsa, s egyben egy sajátos szemléletű szociálpszichológiát alkosson. Közvetlen kiindulópontja Durkheim elmélete volt és a kollektív reprezentáció fogalma, melyet - a mestertől eltérően - nem az individuum számára adottságként jelentkező társadalmi folyamatokból, hanem a közösségbe ágyazott egyéni motivációból és a kommunikációs folyamatok által összekötött egyéni megismerésből vezet le. Ezt az elgondolást igyekszem az alábbiakban vázlatosan bemutatni, $\mathrm{s}$ két frissebb példát is kerestem a társadalom számára valamilyen értelemben kihívást jelentő (egyetemes emberi jogok és genetikailag módosított élelmiszerek) tárgykörökben a hétköznapi reprezentáció kialakulásának vizsgálatára.

\section{Társadalmi reprezentáció}

A világ közös felfedezésére nem csak olyan nagy presztízsü társaságok, mint a Magyar Tudományos Akadémia vagy egy egyetemi tanszék tagjai szövetkezhetnek. Moscovici $(1984,2002)$ azt állapította meg, hogy hétköznapi emberek, kávéházakban, klubokban (ma talán inkább internetes fórumokon) is ilyen közös megismerésre vállalkoznak, erre utalt a „gondolkodó társadalom” utóbb híressé vált kifejezé- 
sével is. Azon túl, hogy emancipálni igyekezett ezzel a hétköznapi élet különbözö társas-társadalmi színtereit, azt is állította, hogy ezek a hétköznapi helyszínek kikristályosodási pontjai a nagyobb társadalmi folyamatoknak. Ezeken a helyeken, ilyen társadalmi környezetben teszik fel az emberek a világ megértésével kapcsolatos alapvető kérdéseiket, itt magyarázzák el egymásnak a számukra fontos összefüggéseket, ezáltal értik meg a magyarázatra szoruló jelenségek okait és következményeit.

A közös megismerés által kialakított hivatkozási keretet sokféle hasonlattal lehet érzékeltetni, és számos szerző meg is tette ezt már korábban. Egy, talán kevesebbet használt párhuzammal, a festői perspektívateremtés, a három dimenzió kettőben ábrázolásának példáján jól érzékelhetjük, hogy a közös nézőpont miként vezethet el a lehetséges végtelenszámú reprezentáció közül a világ egybevágó leképezéséhez. A reprezentáció - ismerjük a reneszánsz festők törekvéseiből - ebben az esetben elválaszthatatlanul tartalmazza az eredeti információt és annak (re)konstrukcióját. Ugyanazon eszközök szolgálnak a „kint” lévő valóság ábrázolására, melyek konstruálják a tárgyak viszonyait és ezek jelölik ki a befogadó nézőpontját is. Ebböl a nézőpontból mögöttes szervezőelvek szerint teremtik újra, aktív alkotó folyamatként a valóságot. A társadalmi megértésnek is része a közös perspektíva kijelölése, ugyanakkor e közös nézőpontból indul ki az új események, összefüggések (akár tudományos elméletek) reprezentációja, itt válik elhelyezhetővé minden új tudás.

A kommunikáció során egymás között megosztott elképzelésekből álló reprezentációs univerzum (világkép), Moscovici szerint, stabilitást ad a cselekvések és a társas kapcsolatok, társadalmi viszonyok megszokott rendjén keresztül. Az új ismeretek - származzanak tudományos vagy más normatív forrásból - átszürődnek a meglévő közös reprezentáción, ezáltal át is alakulnak, ám a biztonságosan megragadott formájukban újat is hoznak a közösségnek. A 20. század közepén - a pszichoanalitikus elmélet hétköznapivá válását vizsgálva - Moscovici (1961/1976) ugyanakkor nem a személyes beszélgetésekben, hanem a tömegkommunikációban, annak különböző csatornáin mutatta ki a befogadás folyamatát. A modern társadalomban valóban több módon is megteremthető az az interakció, mely a közös reprezentációt kialakítja. Fontos a személyes kommunikáció, ám nem állítható szembe a tömegkommunikációval, mindkettő szolgálhatja a hétköznapi reprezentáció kialakítását. A laikus megismerő az ismeretlent igyekszik általuk becserkészni, és az otthonos biztonságot nyújtó korábbi tudásába ágyazni. Paradigmaalkotó kutatásában Moscovici sajátos módon egy tudományos elméletet választott kiindulópontul. A pszichoanalízis főbb fogalmainak és összefüggéseinek (pl. elfojtás) átalakulását vizsgálta a korabeli francia sajtó és a közvélemény tükrében (lásd magyarul László, 1999), melynek során az elvont elképzelés a hétköznapi befogadók meglévő tudásához, értékeihez és normáihoz alakult.

A szociális reprezentáció elméletének kritikusai gyakran állítják párhuzamba a szociális reprezentációs folyamatokat az egyéni megismerési folyamatokkal, 
mondván, hogy az előbbiek semmi újat nem jelentenek az utóbbiakhoz képest. Az elmélet képviselői szerint azonban ez félrevezető. A társadalmi reprezentáció azért nem hasonlíthat a kognitív sémákra, kategóriákra, mert más folyamatok hozzák létre. Az egyéni kogníció mechanizmusai (pl. egyéni információfeldolgozás, emlékezés) helyett egy velejéig interperszonális folyamat, a kommunikáció közvetít a meglévö tudás és az új jelenségek, az újonnan befogadott összefüggések között. A szociális reprezentáció tehát nem vizsgálható az egyénen belül, ha figyelmen kívül hagyjuk, vagy tudatosan kizárjuk azokat a társas-társadalmi folyamatokat, melyekben az egyéni érzések, gondolatok benne foglaltatnak. Feltétlenül szükséges e folyamatok vizsgálata, hiszen egy közösség tagjai rajtuk keresztül osztják meg világképüket, s így helyezik abban el az új tudást. A szociális reprezentáció elmélete tehát, legalábbis Moscovici törekvéseiben, a társas-társadalmi lét egészét igyekszik magyarázni, ahol az interperszonális kapcsolatokban felépülő társadalmi viszonyoktól haladunk az egyedi reakciókig, attitüdökig, s nem fordítva. A közösen felépített és fenntartott reprezentáció áll az általa vizsgált társas-társadalmi folyamatok fókuszában, ennek közösségteremtő erejét, egyéni és közös viselkedést meghatározó voltát vizsgálja. A reprezentáció a viselkedés irányításában a térkép szerepét tölti be, átfogó dimenziókkal szolgál, összeköti a különböző jelenségeket, s így alakítja a cselekvést. A közös megismerés motorja az általános emberi motiváció, hogy a megismeréssel az idegen, a zavaróan ismeretlen ismerőssé formálódjon.

A szociális reprezentáció fogalma maga is jó példa arra, hogy milyen jelentősége van a megnevezésnek. Sok rokon fogalmat találunk a szociálpszichológiában és általában a társadalomtudományokban, így a közvéleményt, az attitüdöket, azok rendszereit, ideológiát, társadalmi kategóriákat és sémákat, melyek már használatosak voltak ezt megelőzően is. Ezekkel a fogalmakkal is megragadható a szociális reprezentáció elméletének egy-egy fontos aspektusa, mégis új fókuszt ad a - több évtizednyi múltjában változó sikereket elért - Moscovici-féle elgondolás (legalább annyira kutatói szemléletként, mint szigorúan megfogalmazott elméleti modellként), a társas-társadalmi és az egyéni megismerés közötti alkotó kölcsönhatás megragadásában. Más, a francia kultúrában gyökerező és a huszadik század eleji francia társadalomtudományi (szociológiai, kultúrakutatói) elgondolások is hasonló célt tüznek ki, azonban ezek többszörös áttételeken keresztül hatnak csupán az emberi megismerés pszichológiai elméleteire. Moscovici elmélete maga is ilyen közvetítöként fogható fel, Lévy-Bruhl és Durkheim elgondolásai, valamint a pszichológiai jelenségszint között.

A személyes- és tömegkommunikációban megvalósuló társas-társadalmi interakció előtérbe állítása különbözteti meg a szociális reprezentációk kutatóit a reprezentációt egyik oldalról a kollektív, másik oldalról az egyéni folyamatokkal magyarázó más elképzelések képviselőitől. Elvetik a társadalmi, de a kognitív szemlélet redukcionizmusát is, az egyéni megismerés náluk nem technologizálható mechanizmus, a megismerő személyes törekvései és közösségi viszonyai (csoport- 
hoz tartozása, más csoportokkal szembenállása) határozzák meg. Egy másik sajátossága az elméletnek, hogy a reprezentáció nem csupán a megismerés struktúráját jelenti, de magában hordozza a változás feszültségét is. A tudás tartalmának leírása mellett alkalmazható a változás dinamikájának megragadására is. A reprezentáció (a reprezentálás folyamata) nem pusztán követi a külső változásokat, hanem sajátos belső dinamikája van. Ismeretelméleti dinamikájára jellemzö, hogy azt vizsgálja, miként válik az ismeretlen ismerőssé, hogyan kapcsolódik a már ismert világhoz. Emellett a reprezentáció kialakításának csoportdinamikája is van, amely egyrészt a csoporton belül az egyetértés irányába, másrészt a más csoportoktól való megkülönböztetés felé hat.

A szociális reprezentáció, mint termék lényegében az „érdeklődő megfigyelők" (Moscovici, 1981) laikus tudása, ami különbözik nem csupán a tudományos elméletektől, de a politikai ideológiáktól is. Moscovici egyébként ezt két utóbbi reprezentációs módot a dologiasított (reifikált) világ részének tartja, szemben a hétköznapi élet konszenzuális világával. A hétköznapi megismerők világában a formális logikát nem a teljes irracionalitás váltja fel, hanem az emlékezés veszi át a logikai következtetések szerepét, a múlt dominálja a jelent, ám a következmények legalább annyira fontosak, mint az okok egy jelenség magyarázatában. A hétköznapi megismerő hajlik arra, hogy az új információt úgy használja, hogy az megerősítse korábbi ismereteit. A társas-társadalmi dinamika azért is meghatározó, mert a szociális reprezentáció hatékony hétköznapi csoportdinamikai eszköz a közösségbe való befogadáshoz vagy elkülönüléshez, végső soron kirekesztéshez. Ugyanakkor tévedés volna, ha úgy tekintenénk az ismerőssé tétel ezen folyamatára, mintha automatizmusok és feldolgozási hibák alkotnák elsősorban. Az egyéni megismerésre koncentráló információfeldolgozási megközelítések hajlamosak arra, hogy a hétköznapi megismerést a hibákon keresztül talán túlzottan is kritikusan szemléljék. A szociális reprezentáció elméletében az elemzés célja az, hogy kimutathatóvá váljon az a metaszint, melyen társas-társadalmi folyamatok alakítják és korlátozzák az egyéni reprezentációkat és attitüdöket.

\section{Reprezentáció: folyamat és struktúra}

Az előbbiekben már láttuk, hogy a reprezentáció (reprezentálás) kettős jelentést hordoz, melyet kibont a szociális reprezentáció elmélete. Egyrészt a folyamatot magát elemezve, megkülönbözteti a lehorgonyzás és a tárgyiasítás mechanizmusait. A lehorgonyzás során a közösség az új ismereteket elhelyezi fogalmainak már kialakított hálójában. Két részre bontható ez, a klasszifikációra, a meglévő tudásstruktúrában történő elhelyezésre, illetve az értékelésre, mely az új tudáselemmel kapcsolatos viszonyt formálja. A tárgyiasitást Moscovici (1981) elsősorban a modern társadalmakban megfigyelhető általános tendenciának tartja, melynek során a gondolkodás és a nyelv sajátos eszközeivel az absztrakt fogalmak kézzel fogható 
tárggyá, mechanizmussá alakíthatók a reprezentációban. A tárgyiasítás társas funkciója, hogy kiszakítsa az eredeti (tudományos, ideológiai stb.) kontextusából a jelenséget és a hétköznapi fogalmakhoz közelítse. Közvetítő és határőrző folyamatként ezért egyaránt felfogható, mely a hétköznapi megismerést övezi.

A pszichoanalízis elméletének figuratív magja például a gőzgép lett, mely a feszítő ösztönök és az elfojtások, szublimációk dinamikáját képi, tárgyiasult formában tartalmazza. A figuratív magról azt állapítja meg korai dolgozatában Moscovici (1961/1976), hogy az a reprezentáció központi eleme, szemléletesen szervezi egységgé a különböző részeket. Az elvont, szimbolikus jelenség így válik valóságossá, kézzelfoghatóvá. Így szimbolizálhat egyébként a tudós maga is egy elméletet, öszszefüggést. Sigmund Freud személye a pszichoanalízist, míg a radioaktivitással kapcsolatos elgondolásokat Marie Curie, a relativitáselméletet (ám azon túlmutatóan a modern természettudományt egészében is) Albert Einstein, vagy a második világháborúban Nyugat-Európának nyújtott amerikai segítséget Marshall tábornok maga képviselheti a közvéleményben.

A reprezentáció másrészt felfogható a reprezentálás folyamatának eredményeként is. Ebben az értelemben tekinthetünk rá kialakult struktúraként, mely az érintett tudati elemeket szervezi egységgé. Moscovici elméletalkotói nagyvonalúsága (más vélemények szerint elnagyoltsága) abban is megmutatkozik, hogy a szociális reprezentációt nem egy adott absztrakciós szinten fogalmazza meg a mentális struktúrákban, nem köti egy bizonyos jelenségkörhöz. Ebben a vonatkozásban Piaget séma fogalmához hasonlítható, hiszen feltétlenül tartalmaz összefüggést az elemek között (ennek szervezőelve azonban nem mozgásos séma vagy valamilyen formájú logika, hanem a társas-társadalmi konszenzus) és tudásstruktúraként szervezi a későbbi megismerést. A szociális reprezentáció lehet egy teljes világkép, lehet egy jelenséggel kapcsolatosan kialakított konkrét elképzelés is. Értelmezhetjük például általában a nemzetközi viszonyok rendszereként (Kiss, 2003), de lehet a saját nemzet vagy éppen Európa (De Rosa, 1996, De Rosa és Bombi, 1999) képe is. Ezt a sajátosságát elemzi behatóbban Moliner (1996), amikor saját kutatásaiban megkülönbözteti a kisebb hatókörünek szánt „imázst” (pl. gazdasági szervezet, egyetem képe) a szociális reprezentáció fogalmától.

A különböző reprezentációk általánosítható struktúráját vizsgálja Abric (1994) a figuratív mag fent említett elképzéséből kiindulva. A középpont és a periféria dimenzióját feltételezi minden reprezentációban. A központi mag a reprezentáció nélkülözhetetlen elemeit tartalmazza, melyek nélkül nem beszélhetnénk már ugyanarról a reprezentációról. A központi elemek állnak leginkább ellen a változásnak, ezek a legstabilabb és a leginkább konszenzuális pontjai a reprezentációnak. Fontosnak tartja megjegyezni, hogy a centralitás nem azonos a máshol előforduló kiugró jelleggel, vagy a fontosság egyetlen kvantitatív mutatójával. Leginkább viszonyfogalmakkal ragadható meg: a jelentésháló központi helyén lévő tartalmak alkotják. A középponti mag ún. alkotó funkciója, hogy jelentéssel ruházza fel a reprezentá- 
ció egészét, akár át is alakítva a többi elem eredeti jelentését. Ezen felül szervezi is a reprezentációt azáltal, hogy kapcsolatot képez annak elemei között, stabilizálja, egységesíti a reprezentációt. A periféria szükséges kiegészítője a központi magnak, a reprezentáció ide tartozó elmei sokkal változékonyabbak, időtől, kontextustól inkább függnek. Fontos funkciójuk a (változó) valósághoz alakítani a reprezentációt. Itt válnak lehetővé egyéni különbségek a reprezentációban, ezek az elemek vannak közvetlenebb kapcsolatban magával a viselkedéssel, itt zajlik a reprezentáció átalakulása, illetve megőrzése a változással szemben. Míg a központi magot inkább az átfogó történeti, társadalmi, ideológiai, normatív feltételek alakítják, Abric szerint, addig a periféria inkább van kitéve a közvetlen társas-társadalmi és tárgyi környezetnek. Ebben, a szociális reprezentáció jelentős iskolájává erősödött megközelítésben a reprezentáció struktúrája áll a fókuszban, de a stabilitás és a változás kérdése itt is megfogalmazódó dinamikus aspektus, ahogy azt a fentiekben láthattuk.

Úgy gondolhatnánk, hogy ha szociális reprezentáció kutatása az egyetértés világát igyekszik felfedezni, akkor nem találhatunk benne véleménykülönbségeket. Azonban maga Moscovici (1981) is árnyaltabban fogalmaz, amikor a tudomány és az ideológia szféráival általa szembe állított világot megrajzolja. Az egyetértés itt csupán azt az általános tendenciát jelenti, hogy a már ismertet erősíti meg a hétköznapi megismerő, az egyetértés így válik jellemző tendenciává. A szociális reprezentációk mai kutatásaiban egy másik strukturális megközelítés, a genfi iskolának is nevezhető kutatócsoporté, arra hívja fel a figyelmet, hogy az egyetértés nem jelent teljesen megegyező véleményeket a társadalomban, s a véleménykülönbségeket szervezheti a csoport-hovatartozás.

A genfi iskola alapítója Willem Doise (1993) szerint szociális reprezentációk elsősorban közös referenciapontokat, -dimenziókat jelölnek ki a csoport és az egyéni álláspont számára, és ezzel együtt teret hagynak a személyek és csoportok közötti különbségeknek is. Doise fontos elméleti állítása, hogy a szociális reprezentációkat úgy érdemes felfognunk, mint egy, az egyéni megismerés mögötti társastársadalmi metarendszert, mely alakítja az egyéni megismerést. A metarendszer szabályai változhatnak a különböző társadalmi helyzetekben, egyik esetben a formális logika lehet a gondolkodást szabályozó norma, máskor akár a csoport kohéziójának megőrzése szervezheti a megismerést. A szociális reprezentációkat többnek tartja tehát statikus nézeteknél, nézetrendszereknél, szerinte társas-társadalmi metarendszerként közös referenciapontokat kínálnak, és az eltérő véleményeket megadott dimenziók köré szervezik. E dimenziók mentén jelennek meg azután az egyéni- és csoportkülönbségek, hiszen az elgondolás szerint ezek formálják a szociális interakciót és az egyéni reprezentációs folyamatokat. Munkájában arra hívja fel a szociális reprezentációk kutatóinak figyelmét, hogy az egyetértést és a véleménykülönbségeket azok szerveződési elveivel, dimenzióival együtt igyekezzenek feltárni. Ennek jó példája az alapvető emberi jogok reprezentációjának vizsgálata, amely egyben első példánk arra, hogy miképpen lehet a társadalmi megismerés 
szociális reprezentáció elméletének segítségével megragadni a véleményformálás jelenségeit és folyamatait.

\section{Az emberi jogok szociális reprezentációja}

Az emberi jogok vizsgálatában elsőként a közös kiindulópontot keresik Doise és munkatársai a szisztematikusan felépített kutatási programmá összeálló kutatássorozatukban (Doise, 2001; Doise et al., 2003). Az egyetemes emberi jogok jól kiválasztott tárgynak bizonyultak, hiszen a szociális reprezentáció-kutatások alapsémáját követve rá lehetett mutatni egy, a hétköznapi világon kívüli, leginkább talán ideológiai vagy normatív-jogi reprezentációnak tekinthető dokumentumként az Egyetemes Emberi Jogok Nyilatkozatára, melyet a második világháború után fogadott el az ENSZ. Számos területre kiterjed ez a nyilatkozat, így az alapvető elvekre (pl. egyenlőség, szabadság, méltóság), az egyéni jogokra (pl. törvény előtti egyenlöség), egyének közötti kapcsolatokra (pl. családhoz való jog), közügyekre (pl. véleményszabadság), gazdasági és szociális jogokra (pl. pihenésre, szabadidőhöz való jog) és a nemzetközi joggal, - renddel kapcsolatosakra. A történelemkönyvekböl tudjuk, hogy a közös nyilatkozatba foglalt jogok fölött már elfogadásukkor éles viták zajlottak, mert a felek megoszlottak kizárólag az egyéni jogok, illetve a szociális-gazdasági jogok kiterjedtebb érvényesítését pártolókra. Hasonló ellentéteket érdekes módon mind a mai napig találtak a kutatók a laikus vélemények között is. Doise és munkatársainak megközelítésében a szociális reprezentációk kutatása három lépésben történt: elsőként a közös pontokat keresték a reprezentációban, azután az egyéni és csoportközi különbségeket mérték fel, majd végül a különbségeket szervező dimenziókat igyekeztek feltárni.

A reprezentáció közös pontjainak kijelölésében elsőként azt vizsgálták, hogy mennyire értenek egyet a hétköznapi válaszadók abban, hogy milyen típusú jogsérelmek tartoznak az emberi jogok nyilatkozata alá. A több európai országból származó válaszadók ítélete távolról sem volt egyöntetü, azonban a prototipikusság három szintjén álló (nyilvánvalóan az emberi jogokat érintő, az emberi jogokat expliciten nem érintő és nyilvánvalóan azzal kapcsolatban nem lévő) jogsérelmek megítélésében a többség véleménye egy irányba mutatott minden egyes nemzeti almintában. Már ebben a korai vizsgálatban is azt találták a kutatók, hogy az egyéni vélemények különbségét az állami beavatkozással való szembenállás, a fatalizmus-egyéni felelősség dimenziója, és a társadalmi gondoskodás (anómikus) elutasítása szervezte.

A vizsgálatsorozat későbbi pontján egy, a világ 35 országára kiterjedő kutatásban a Nyilatkozat teljes szövegét bemutató kérdőívet készített a kutatócsoport, melyben a válaszadók nyolc kérdésben ítélték meg minden egyes cikkellyel kapcsolatban a személyes érintettségüket, a támogatásuk mértékét, az állami törekvések és az egyéni erőfeszítések hatékonyságát. A kérdőív második felében a személyesen fontosnak 
tartott értékeiket jelölték meg, számot adtak az általuk észlelt társadalmi diszkrimináció és a személyek közötti konfliktusok mértékéről, nyilatkoztak a társadalmi igazságosság magyarázataival kapcsolatban.

A cikkelyekkel kapcsolatos válaszok a hierarchikus klaszterelemzés eredménye alapján két fő csoportba és két-két alcsoportba szerveződtek. Ezek viszonylag pontosan tükrözték az egyetemes emberi jogok fent felsorolt hivatalos, az alkotók szándékai alapján készült osztályozását. Az első fő kategóriát az inkább szociális (szociális-gazdasági, közéleti, személyek közötti) és az alapvető egyéni jogok (élethez való jog, kínzás és rabszolgaság elleni védelem) alkották, míg a másik nagyobb kategória a megítélők válaszai alapján a törvény előtti egyenlőséggel és méltányos ítélethozatallal kapcsolatos egyéni jogok és a társadalmi renddel kapcsolatos cikkelyek voltak. Az elemzések azt mutatták, hogy minden országban a válaszadók számára fontosabbak voltak az alapvető egyéni és szociális jogok, mint a többi jog. Az előbbiek szembeállítása azonban szintén általánosan megfigyelhető volt a hierarchikus elemzés alacsonyabb szintjén, tehát a késői közvéleményben is felfedezhető az ENSZ-t annak idején megosztó vita az egyéni versus széles szociális jogokról.(Lásd 1.ábra)

Az emberi jogokkal kapcsolatos véleményeknek erős kulturális társadalmi meghatározottságuk van, ezért fontos lépése volt a kutatásnak, hogy a válaszokat két módon is elemezték: a kultúrákat átfogó elemzésben az egyéni válaszokat a nemzeti hovatartozástól függetlenül vitték be, míg az egyéni szintü (kultúrafüggetlen) elemzésben viszont kivonták a nemzeti átlagokat a válaszokból, így azok a nemzeti mintán belüli egyéni különbségeket mutatták. A két párhuzamos elemzés eredményei nagymértékben együttjártak, mindkét módszerrel sikerült négy válaszadói csoportot azonosítani:

- minden skálán az emberi jogok iránt nagyfokú elkötelezettséget mutató szószólók,

- személyi elköteleződést mutató, ám az állam szerepvállalásában nem bízó, egyénként elkötelezettek,

- az emberi jogok érvényesülésével kapcsolatban pesszimista állásponton lévő szkeptikusok,

- saját erejükben kevésbé, ám az állam szerepvállalásában inkább bízó állampártiak.

A háttérváltozók (értékválasztások, észlelt konfliktusok) alapján az emberi jogok iránt inkább elkötelezett szószólókra és állampártiakra az univerzalizmus értékorientációja és a társadalmi igazságtalanság rendszerszintü magyarázata volt jellemző. Az egyéni álláspontok különbségét szervező egyik dimenzió tehát az univerzalista értékelkötelezettség és a társadalmi diszfunkciók okozta problémák tudatosítása volt. Az elemzések azt mutatták, hogy az emberi jogokkal kapcsolatos véleményeket az emberi természetből vagy a gazdasági viszonyokból következönek ítélt, és személyesen is átélt társadalmi igazságtalanság, diszkrimináció is szer- 
vezte, mely elsősorban az egyéni elkötelezett és a szkeptikus válaszadóknál volt megfigyelhető. A kultúrától függetlenül megjelentek tehát az egyes jogokkal kapcsolatos véleménykülönbségek.

Cikkelyek

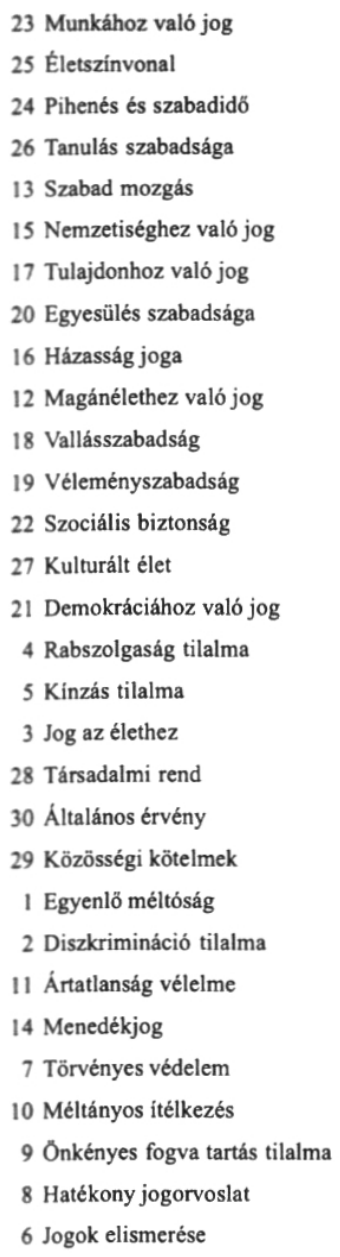

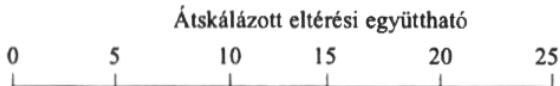

(5)

(5)

(5)

(5)

(3)

(3)

(4)

(3)

(3)

(4)

(4)

(5)

(5)

(4)

(2)

(2)

(2)

(6)

(6)

(6)

(1)

(1)

(2)

(3)

(2)

(2)

(2)

(2)

(2)

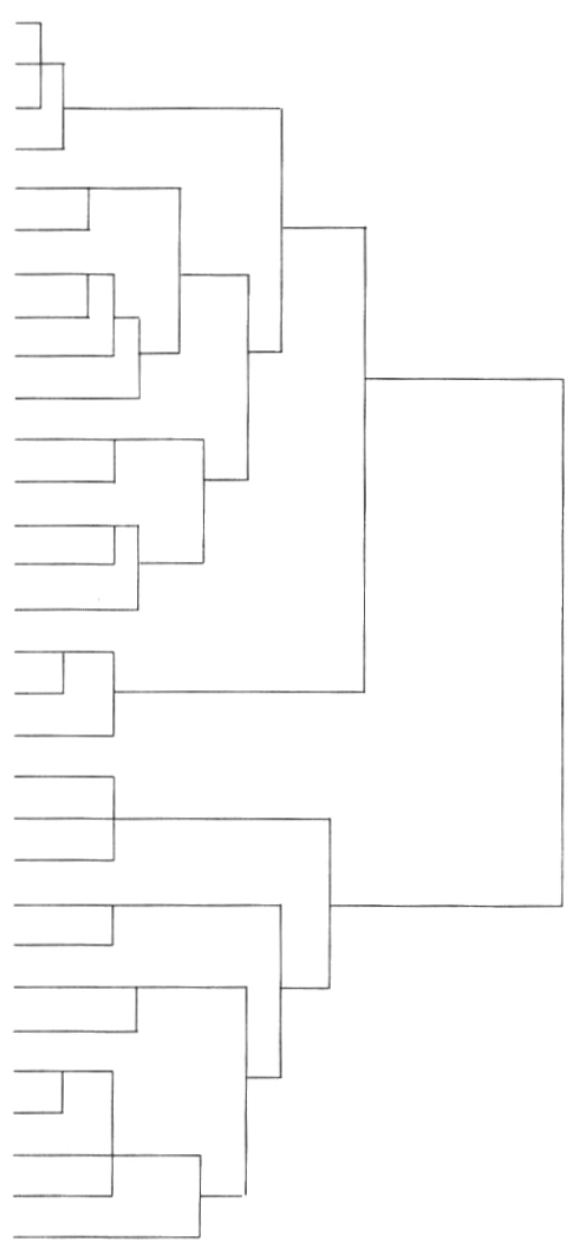

Megjegyzés: A zárójelben lévő számok Cassin osztályozásának felelnek meg (1: alapelvek; 2: egyéni jogok; 3: emberi kapcsolatokra vonatkozó jogok; 4: közéleti jogok; 5: szociális-gazdasági jogok; 6: társadalmi rend). Az eltérés együtthatóit átskáláztuk.

1. ábra: A 30 cikkelyre adott válaszok hierarchikus klaszterelemzésének eredménye (Forrás: Doise et al., 2003, 311. o.) 
A Doise és munkatársai által végzett kutatás egyik fontos célja volt, hogy a nemzeten belüli és a nemzetek közötti különbségeket is egybevessék. A 35 ország válaszátlagai között természetesen voltak különbségek: a japán és az indiai mintában találtak legnagyobb számban szkeptikusokat, az egyéni elkötelezett válaszadók az emberi jogokat kevésbé tiszteletben tartó államokban, míg az állampártiak inkább a fejlett országokban és az éppen rendszert váltott országokban jelentek meg. Ezzel együtt azt olvasták ki az eredményekből, hogy az emberi jogokkal kapcsolatos normatív szociális reprezentáció nem kultúrafüggő, alapvetően hasonlónak látták a válaszadók véleményét a legkülönbözőbb földrészeken, számos különböző országban. A különbségeket valószínüleg a kulturális tapasztalatok is szervezik (pl. az ország emberi jogi helyzete), ám ezeken felül is hatott a jogsérelem személyes megtapasztalásán és az értékelkötelezettségen nyugvó egyéni nézőpont szervezőereje. Nem csupán tudományos kérdés, praktikus következményei is vannak, ha a kutatók bizonyítékkal tudnak szolgálni arra, hogy az emberi jogok nem a nyugati kultúra erőszakos terjesztésének eszközei a világban, ti. egyrészt széles körben megjelenő egyetértést találunk bennük, másrészt a kultúrákon átívelő véleménykülönbségeket is felfedezhetjük. Doise és munkatársainak kutatását nyilván ez a cél is mozgatta. Ezzel együtt a jogi-normatív szabályokat leképező hétköznapi reprezentációkra is jó példával szolgáltak. Sőt a reprezentáció szerveződésének általános elveit is érzékeltetni tudták.

\section{A genetikailag módosított növények szociális reprezentációja}

Másik példánk a szociális reprezentáció müködését más területen, az életünket átszövő tudományos-technikai újításokkal kapcsolatosan mutatja be. A tömegkommunikáció szerepét, illetve a fenyegető ismeretlen jelenséggel való kollektív megküzdés lépéseit is nyomon tudjuk követni a szintén több országra kiterjedő kutatásban. Wagner és munkatársai (2002) számos európai országban kiterjedt adatgyüjtés nyomán, elméleti és módszertani újítókedvvel elemezték a genetikailag módosított élölényekkel kapcsolatban alakuló közvéleményt. Azt találták, hogy a fenyegető képi ábrázolás alapvető szerepet játszik a géntechnológiával kapcsolatos reprezentáció kialakításában. Kollektív szimbolikus megküzdésnek nevezték el azt a folyamatot, melynek során képekkel és másféle reprezentációkkal igyekeznek ismerőssé, megvitathatóvá tenni egy közösség számára a fenyegetőnek tủnő új technológiai, tudományos eredményeket. Elgondolásukat egy-két sajátossága mentén megkülönböztetik a szociális reprezentáció elméletétól, még ha a szoros kapcsolatot maguk sem tagadják. Az általuk leírt kollektív szimbolikus megküzdést inkább kötik az új technológiák befogadásának jelenségköréhez; a képzelet által uralt folyamat szerintük nem eredményez teljesen kidolgozott szociális reprezentációt; illetve előtérbe helyezik, hogy a modern közvéleményben oda-vissza átjárhatók a képi, a képzeleti és a tudományosan alátámasztott nézetrendszerek. 


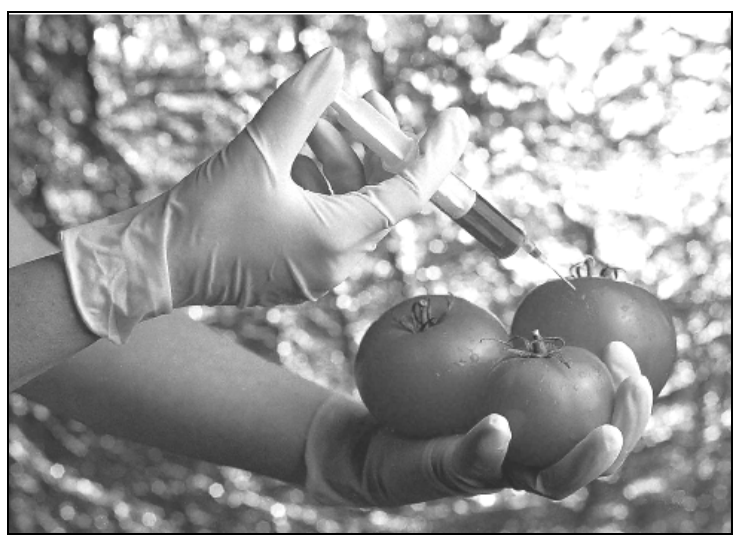

2. ábra: Ausztriában a geneteikailag módosított élölényekkel kapcsolatos tipikus képi ábrázolás (Forrás: Wagner et al., 2002, 333. o.)

Középpontba a megküzdés fogalmát helyezik, ami nem hiányzik a szociális reprezentáció elméletéből sem, hiszen az ismeretlen megszelídítése Moscovici eredeti elképzelései szerint is központi motívuma a közösség reprezentációs törekvéseinek. A pszichológiában általánosan használt megküzdés fogalmával való rokonságot annyiban megerösítik, hogy az általuk leírt kollektív forma is többé-kevésbé tudattalan, nem kontrollált folyamatokat igyekszik megragadni, még ha tartalmaz is megismerési összetevőt. Természetesen a kollektív megküzdésben is alkotó részt vállalnak az egyéni törekvések, nem kizárólag az individuum feje fölött zajlanak ezek a folyamatok sem. Hangsúlyozzák azonban a média szerepét, amely a szenzációt keresve az újat figyelemre méltónak, a szokásokkal, a meglévő helyzettel szemben kihívást jelentőnek állítja be.

A választott témával kapcsolatban érdemes megjegyezni, hogy a biotechnológiai beavatkozásokkal kapcsolatban nem a tudományos nézőpont uralja a közvéleményt, még ha ennek kitüntetett szerepe is van. Különböző civil szervezetek, politikusok is aktív résztvevői a vitának, ahol a formálódó közvélemény nem végeredmény, hanem maga is kiindulópontja, hivatkozási alapja akár a szabályozásnak is. A genetikai változtatásokkal kapcsolatban a laikusok, civil szervezetek, politikusok, hatóságok is határozott álláspontot fogalmaznak meg. Az állami szervezeteknek és kormányoknak lenne a feladatuk mai társadalmi szerepmegosztásban, hogy a technológiai újítások ártalmas következményeitől megóvjanak. Wagner és munkatársai kollektív tárgyi megküzdésnek nevezik a szakértők, hivatalnokok és hivatalok erre irányuló cselekvését. A téma „specialistái” mellett azonban maguk a hétköznapi emberek is kialakítanak valamilyen fogalmat, tulajdonítanak valami jelentést, s az ő reakciójukat nevezik kollektív szimbolikus megküzdésnek. Még pontosabban, a kol- 
lektív szimbolikus megküzdést a kollektívum erőfeszítésként könyvelik el. A kollektív szimbolikus megküzdésnek négy fázisát különböztetik meg.

Az első a veszélytudat szakasza, melyben az új jelenség a közvélemény meghatározó része számára fontosnak és aktuálisan megválaszolandónak mutatkozik. Leggyakrabban a média által felerősített politikai-közéleti szembenállás váltja ki ezt a társadalmi tudatosulást, azáltal hogy napirenden tart egy adott témát. A génmanipuláció esetében a technológiát életidegennek, beláthatatlan következményekkel járónak és a hétköznapi életet is átalakítónak állítják be. A növények és állatok furcsa új tulajdonságai kerülnek előtérbe. A második fázisra a divergencia jellemző, amikor a hétköznapi megismerők az új, ismeretlen jelenség megragadására a legkülönfélébb korábbi tudást vagy képzeleti képet aktiválják, amely definíció szerint nem kapcsolódik adekvát belső reprezentációhoz.

A harmadik fázis a konvergencia, melynek során a felhozott különféle értelmezéseket, megfogalmazásokat a nyilvános kommunikáció megrostálja. A többségi vélemény egyes értelmezéseket kiiktat, másokat pedig felerősít. Kialakul a jelenség komplex, ám mégis könnyen megragadható reprezentációja, ami a lényegi vonásokat magába foglaló metafora, kép, szimbólum formáját is öltheti. A konvergencia fókuszpontját nem a tudományos igazság, nem is a véletlen jelöli ki, hanem a közösség meglévő világképe, és az új jelenség ebben megtalált helye. Wagner és munkatársait ez a szakasz érdekli leginkább, hiszen itt lehet a reprezentáció kialakulásának folyamatait nyomon követni. Ezek között a Bartlett sémafogalmához tartozó konvencionalizációt, a nézetek terjedésében a ,járványtani” gondolatot továbbvivő kulturális antropológus Sperber gondolatait és a szociális reprezentáció kutatásában az utóbbi időben újra felerősödő képi reprezentációs kutatásokat emelik ki.

A negyedik fázist normalizációként fogalmazzák meg, amikor a közösség szimbolikus megküzdése nyugvó pontra jut. Azt is állítják, hogy az így kialakult reprezentáció egyben ki is kerül a nyilvánosságból, elszürkül azáltal, hogy nem tünik már a közvélemény számára fenyegetőnek. A szimbolikus - ebben a megközelítésben a morális pánikként leírt jelenséghez hasonló, felfokozott reakcióként jelentkező - kollektív reprezentációk helyét - szerintük ebben a fázisban - fokozatosan átvehetik a tudományos vagy bürokratikus magyarázatok. A folyamat azonban nem egyirányú, újabb hullámokban újra a közvélemény középpontjába kerülhet a korábban abból kiesett téma, jelenség. Ebben az utolsó szakaszban látszik leginkább, hogy Wagnert és munkatársait mi motiválhatta, hogy az általuk leírtakat formálisan megkülönböztessék a társadalmireprezentáció-elmélettől. A tömegkommunikáció eseményeit állítják előtérbe, ezért veszítik el az ebből kikerülő - de a közvélemény mélyebb rétegeiben valószínüleg tovább élő - reprezentációt miután a közös vélemény kialakul. A kollektív szimbolikus megküzdést átmenetisége a morális pánik (lásd Császi, 2003) újabban megragadott jelenségéhez közelíti, aminek azonban a megerősített társadalmi normákban, ideálok alakításában tovagyürüző hatását már nem vizsgálják szerzőink. 
Az 1996-ban és 1999-ben, több európai országban párhuzamosan végzett közvélemény-kutatással Wagnernek és munkatársainak alkalma volt a reprezentáció változását és társadalomhoz kötöttségét is nyomon követni. A kiindulópont a közoktatásban elsajátítható, a biotechnológiához kapcsolható tudás volt. (Például: „Az élőlények klónozása teljesen megegyező utódot eredményez.” Vagy: „Léteznek olyan baktériumok, amik a szennyvízben élnek.") A kutatók a képi megjelenítést igyekeztek állításokká formálni, s így ütköztették a meglévő tudással. (Például: „A közönséges paradicsomban nincsenek gének, míg a genetikailag módosítottakban vannak." Vagy: „Genetikailag módosított gyümölcsöket fogyasztó személy génjei is megváltozhatnak.") A kérdőíves kutatást kiegészítették médiakutatással és szakpolitikai döntések elemzésével. A vizsgálat eredményeként kimutatható volt, hogy egyes országokban a kollektív szimbolikus megküzdés különböző fázisaira jellemző közvélemény alakult ki. Általában a tudományos eredményeket közvetítö tankönyvi tudás alacsony szintjeit sikerült regisztrálni, míg a közkeletủ, adott esetben képekbe foglalt állítások (a genetikai módosítás plusz anyagot visz be az élölényekbe, mely tovább terjed a fogyasztásuk által stb.) széles körben megfigyelhetők voltak a közvéleményben. Éppen a tudományos megalapozottságú és a médiában közölt képekböl levezethető állításokat elfogadó (elutasító) „nem tudom” válasz arányain keresztül igyekeztek bemérni, hogy a kollektív szimbolikus megküzdés melyik fázisában áll az adott európai ország közvéleménye. Érdekes adalék, hogy a más kutatásokban inkább kizárni igyekezett „,nem tudom” válasznak itt nagy jelentőségét látták: a problémával még nem szembesült (megküzdés elötti) közönséget ez különböztette meg az aktuális megküzdésben és az azutáni fázisban lévő közvéleménytől.

A megismerés társadalmi aspektusait különféle tárgykörökben és megközelítésben megmutató fenti elméletek, modellek és empirikus eredmények fontos adalékul szolgálhatnak ahhoz, hogy megértsük a tudományos elméletekből vagy más normatív forrásokból származó, logikai vagy morális értelemben mércét jelentő tudás elsajátítását. Bár végleges választ nem adnak a racionalitás társadalmi meghatározottságával kapcsolatosan több oldalról felmerülő elméleti kérdésekre, azt mindenesetre megállapíthatjuk általuk, hogy a hétköznapi életben legalább annyira vagyunk vitatkozó, kommunikáló emberek, mint formális logikát érvényesítő naiv tudósok. $\mathrm{Az}$ is fontos tanulság, hogy tudományos vagy másként rögzített normatív reprezentáció hogyan lép a hétköznapi megismeréssel kölcsönhatásba, s hogy ez a dinamikus folyamat milyen szisztematikusan feltárható összetevőkkel bír. A vizsgálat eredménye pedig nem csak a társadalmi müködés, de az egyén reprezentációira és a világ megismerésére, a nem iskolás helyzetekben megtapasztalt, de a legtermészetesebb értelemben vett tanulás teljesebb megértéshez is vezethet. 


\section{Irodalom}

Abric, J-C. (1994): L'organisation interne des representations sociales: système central et système périphérique. In : Guimelli, C. (Ed.): Structures et transformations des représantions sociales. Delachaux et Niestlé, Neuchatel et Paris.

Császi Lajos (2003): Tévéerőszak és morális pánik. Új Mandátum, Budapest.

De Rosa, A. S., Bombi, A. S. (1999): Se sentir hereux d'etre Italiens? La construction de l'identité nationale et supranationale dans les representations sociales de son pays ou du pays d'autrui chez des enfants et chez des adolescents. In: Rouquette, M-L. - Garnier, C. (Eds.): La genèse des representations sociales. Éditions Nouvelles, Montréal, 136-170.

De Rosa, A. S. (1996): Reality changes faster than research: National and supranational identity in social representations of European Community in the context of changes in international relations. In: Breakwell, G. - Lyons, E. (Eds.): Changing European Identities. Advances in Social Psychology. Butterworth-Heinemann, Oxford, 381-402.

Doise, W. (1993): Debating social representations. In: Breakwell, G. M. - Canter, D. V. (Eds.): Empirical Approaches to Social Representations. Clarendon Press, Oxford, 157-170.

Doise, W. (2001): Human rights studied as normative social representations. In: Deaux, K. - Philogéne, G. (Eds): Representations of the Social. Blackwell, Oxford, 96-112.

Doise, W., Spini, D., Clémence, A. (2003): Az emberi jogok mint szociális reprezentációk vizsgálata kultúrközi összehasonlításban. In: Váriné Szilágyi Ibolya (szerk.): Értékek az életben és a retorikában. Pszichológiai Tanulmányok XIX. Akadémiai Kiadó, Budapest, 301-327.

Kiss Paszkál (2003): Between East and West: Hungarians Perceiving Other Nations and Europe. Doktori értekezés, Szociális Reprezentáció és Kommunikáció Európai Doktori Iskola, kézirat.

László János (1999): A szociális reprezentáció-elmélet. In: Társas tudás, elbeszélés, identitás. A társas tudás modern szociálpszichológiai elméletei. Scientia Humana, Kairosz. 9-41.

Moliner, P. (1996): Images et Représentations Sociales. De la théorie de représentations à l'études des images sociales. Presses Universitaires de Grenobles, Grenoble.

Moscovici, S. (1984): The phenomenon of social representations. In: Moscovici, S. - Farr, R. (Eds.): Social Representations. Cambridge University Press, Cambridge, 3-69.

Moscovici, S. (1961/1976): La psychanalyse: son image, son public. Presses Universitaires de France, Paris.

Moscovici, S. (1981): On social representations. In: Forgas, J. (Ed.): Social Cognition. Perspectives on Everyday Understanding. Academic Press, London, 181-209.

Moscovici, S. (2002): Társadalom-lélektan. Osiris Kiadó, Budapest.

Piaget, J. (1965/2005): Szociológiai tanulmányok. Osiris Kiadó, Budapest.

Wagner, W., Kronberger, N., Seifert, F. (2002): Collective symbolic coping with new technology: knowledge, images and public discourse. Br. J. Soc. Psychol. 41, 323-343. 